\title{
- PRÓBA PORÓWNANIA JAKOŚCI OPIEKI ZDROWOTNEJ W WOJEWÓDZTWACH MAZOWIECKIM I PODLASKIM - BADANIA PILOTAŻOWE
}

\section{COMPARISON OF HEALTH CARE QUALITY IN MAZOVIA AND PODLACHIA}

\author{
Agnieszka Krukiel ${ }^{1}$, Zofia Sienkiewicz ${ }^{1}$, Irena Wrońska², Joanna Gotlib ${ }^{3}$ \\ ${ }^{1}$ Zakład Pielęgniarstwa Społecznego \\ Warszawski Uniwersytet Medyczny \\ ${ }^{2}$ Katedra Rozwoju Pielęgniarstwa \\ Uniwersytet Medyczny w Lublinie \\ ${ }^{3}$ Zakład Dydaktyki i Efektów Kształcenia \\ Warszawski Uniwersytet Medyczny
}

DOI: https://doi.org/10.20883/pielpol.2017.11

\section{STRESZCZENIE}

Wstęp. O poziomie jakości opieki zdrowotnej decyduje kilka czynników, m.in.: jakość realizowanych świadczeń medycznych, jakość opieki pielęgniarskiej, relacje pomiędzy pracownikami, warunki organizacyjno-techniczne, sposób zarządzania opieką zdrowotną.

Cel. Celem podjętych badań było porównanie jakości opieki zdrowotnej w województwach mazowieckim i podlaskim.

Materiał i metody. Badania przeprowadzono w grupie 300 pacjentów wybranych placówek medycznych na Podlasiu i Mazowszu w 2011 r. Anonimowe, dobrowolne badania ankietowe przeprowadzono $z$ wykorzystaniem samodzielnie skonstruowanego kwestionariusza ankiety. Badania nie wymagały zgody Komisji Bioetycznej WUM. Analiza statystyczna: STATISTICA 12,5 (licencja Warszawskiego Uniwersytetu Medycznego), nieparametryczny test statystyczny: chi-kwadrat Pearsona.

Wyniki. Formalności związane z przyjęciem do szpitala są w 42,33\% oceniane dobrze, znacznie wyżej w województwie podlaskim niż województwie mazowieckim $(\mathrm{p}<0,03)$. Równie wysoko oceniana jest dostępność do opieki pielęgniarskiej (47,67\%), nieznacznie lepiej w województwie mazowieckim $(p=0,46)$.

Wnioski. W badanej grupie pacjentów ogólna ocena usług świadczonych przez szpital oraz zadowolenia z kontaktu z personelem medycznym w województwach mazowieckim i podlaskim jest satysfakcjonująca. Społeczna ocena pracy pielęgniarskiej jest wysoka.

StOWA KLUCZOWE: jakość, ochrona zdrowia, pacjenci, opinie.

\section{Wstęp}

W pierwszej połowie XX wieku w placówkach opieki zdrowotnej, głównie stacjonarnych, stwierdzono zły stan opieki zdrowotnej [1-3]. Wnioski te stały się przyczyną i motorem działań zaradczych motywowanych chęcią ulepszenia jakości usług medycznych. Rozpoczęto prowadzenie badań mających na celu określenie stanu wykonywanych świadczeń medycznych [4-7]. Starano się odnaleźć sku-

\begin{abstract}
Introduction. There are several factors that determine quality of health care, i.e.: quality of provided care, quality of nursing care, interpersonal staff relations, organizational and technical conditions, health care management system.

Aim. The aim of the survey was to compare quality of health care in Mazovian and Podlachian voivodships.

Material and methods. The survey was carried out in 2011 in selected medical institutions in Podlachia and Mazovia among 300 patients with a use of a questionnaire.

Results. Formalities related to admission to a hospital are perceived as good by $42,33 \%$, the evaluation was higher in Podlachian than in Mazovian voivodship $(p<0.03)$. Access to nursing care is evaluated equally high (47.67\%), slightly higher in Mazovian voivodship ( $p=0.46)$.

Conclusions. Overall evaluation of services provided by hospital as well as satisfaction with contacts with medical personnel in both Mazovian and Podlachian voivodships are satisfactory. Social evaluation of nurse work is high.
\end{abstract}

KEYWORDS: quality, health care, patients, opinion.

teczną metodę, techniki zapewniające wysoką jakość opieki zdrowotnej. Światowa Organizacja Zdrowia (WHO) organizowała liczne konferencje poświęcone wyżej wymienionym zagadnieniom. W realizowanym przez nią programie Zdrowie 21: Zdrowie dla wszystkich $w X X I$ wieku zaleciła opracowanie technik obserwacji rozwoju jakości opieki zdrowotnej oraz podjęcie badań, które pozwolą określić poziom zadowolenia pacjentów ze świadczonych im usług [7]. 
W Polsce coraz częściej podejmowane są badania, które za cel obierają określenie poziomu jakości opieki zdrowotnej z punktu widzenia pacjenta, organizowane zarówno w pojedynczych placówkach opieki zdrowotnej, jak również w poszczególnych miastach, regionach czy też na skalę ogólnopolską [3, 4, 6, 8-15].

Próby określenia celu badań podejmował Jeanes laureat Europejskiej Nagrody Jakości, który w 1993 r. wypowiedział słowa: „I choć to niesprawiedliwe, nieuzasadnione i bolesne, liczy się jedynie opinia, jaką mają o nas klienci" [16].

Zaobserwowano także, że o poziomie jakości opieki zdrowotnej decyduje kilka czynników, m.in.: jakość realizowanych świadczeń medycznych, jakość opieki pielęgniarskiej, relacje pomiędzy pracownikami, warunki organizacyjno-techniczne, sposób zarządzania opieką zdrowotną [3, 4, 6, 8-15].

Obecnie osiągnięcie jak najwyższej jakości stało się jednym z priorytetów placówek medycznych. Zaś pojęcie normy jakości wzrosło, nie tylko w sferze produkcji, ale również w obszarze usług. Jakość stała się najważniejszą bronią na polu konkurencji rynkowej [16].

\section{Cele pracy}

Cele badań to ocena jakości opieki z punktu widzenia pacjenta oraz porównanie jakości opieki zdrowotnej świadczonej przez placówki ochrony zdrowia w dwóch województwach: mazowieckim i podlaskim.

Szczegółowe cele pracy obejmowały:

- ocenę warunków leczenia szpitalnego (czas oczekiwania w izbie przyjęć, ocena czystości, wyposażenia sal chorych, toalet),

- $\quad$ poznanie opinii pacjentów na temat personelu medycznego i pomocniczego,

- $\quad$ ocenę usług świadczonych przez szpital oraz kontakty chorego z personelem medycznym,

- $\quad$ społeczną ocenę personelu medycznego,

- $\quad$ sprawdzenie, czy dokonywane przez pacjentów z obu wokewództw oceny jakości świadczonych usług medycznych różnią się.

\section{Materiał}

Badaniami objęto łącznie 300 pacjentów dobranych losowo. Grupę I stanowili pacjenci poddani leczeniu w województwie mazowieckim (150 osób). Grupę II stanowili pacjenci leczeni w województwie podlaskim (150 osób). Dobór osób był losowy. Szczegółową charakterystykę pacjentów przedstawiono w tabeli 1.
Tabela 1. Charakterystyka badanej grupy pacjentów Table 1. Characteristics of the study group of patients

\begin{tabular}{|c|c|c|c|c|}
\hline & $\begin{array}{l}\text { Grupa badana/ } \\
\text { Study group }\end{array}$ & $\begin{array}{c}\text { Województwo } \\
\text { mazowieckie/ } \\
\text { Mazovia }\end{array}$ & $\begin{array}{l}\text { /Voivodship } \\
\text { podlaskie/ } \\
\text { Podlachia }\end{array}$ & $\begin{array}{c}\text { Razem/ } \\
\text { Total }\end{array}$ \\
\hline \multirow{4}{*}{ 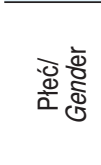 } & kobieta/woman & 86 & 91 & 177 \\
\hline & \% ogółu/\% of the total & 28,67 & 30,33 & 59,00 \\
\hline & mężczyzna/man & 64 & 59 & 123 \\
\hline & \% ogółu/\% of the total & 21,33 & 19,67 & 41,00 \\
\hline \multirow{8}{*}{ 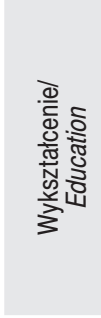 } & podstawowe/primary & 14 & 10 & 24 \\
\hline & \% ogółu/\% of the total & 4,67 & 3,33 & 8,00 \\
\hline & zawodowe/basic vocational & 39 & 21 & 60 \\
\hline & \% ogółu/\% of the total & 13,00 & 7,00 & 20,00 \\
\hline & średnie/secondary & 57 & 43 & 100 \\
\hline & \% ogółu/\% of the total & 19,00 & 14,33 & 33,33 \\
\hline & wyższe/higher & 40 & 76 & 116 \\
\hline & \% ogółu/\% of the total & 13,33 & 25,33 & 38,67 \\
\hline \multirow{6}{*}{ 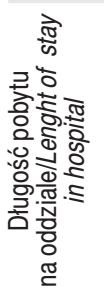 } & do jednej doby/up to 24 hours & 11 & 17 & 28 \\
\hline & \% ogółu/\% of the total & 3,67 & 5,67 & 9,33 \\
\hline & $\begin{array}{l}\text { do jednego tygodnia/ } \\
\text { up to one week }\end{array}$ & 85 & 75 & 160 \\
\hline & \% ogółu/\% of the total & 28,33 & 25,00 & 53,33 \\
\hline & $\begin{array}{c}\text { powyżej jednego tygodnia/ } \\
\text { over one week }\end{array}$ & 54 & 58 & 112 \\
\hline & \% ogółu/\% of the total & 18,00 & 19,33 & 37,33 \\
\hline
\end{tabular}

Źródło: opracowanie własne

Source: author's own analysis

Badana grupa to w 59\% kobiety, a w 41\% mężczyźni. W 38\% z wykształceniem wyższym (38,67\%) - znacznie częściej w województwie podlaskim (25,33\%) niż mazowieckim (13,33\%). Najczęściej przebywający w szpitalu powyżej jednego tygodnia (37,33\%) - nieznacznie dłużej w województwie podlaskim (19,33\%) niż mazowieckim (18,00\%). W województwie mazowieckim (28,33\%) pacjenci częściej niż w województwie podlaskim (25,00\%) przebywają w szpitalu do jednego tygodnia.

\section{Metody}

Badanie przeprowadzone zostało w okresie wrzesień grudzień 2011 r. w wybranych placówkach medycznych w województwach mazowieckim i podlaskim.

Do zgromadzenia informacji wykorzystano ankietę, która składa się z 16 pytań o charakterze zamkniętym oraz 5 pytań dotyczących danych demograficznych. Wszystkie osoby biorące udział w badaniu zostały poinformowane o jego anonimowości oraz dobrowolności uczestnictwa w nim.

\section{Analiza statystyczna wyników}

Uzyskane dane zebrano w arkuszu Microsoft Excel. Analizę statystyczną uzyskanych wyników przeprowadzono w programie STATISTICA 12.5 (licencja Warszawskiego Uniwersytetu Medycznego). W związku z tym, że porównywano dwie niezależne grupy: grupę 
pacjentów z województwa mazowieckiego (grupa I) i grupę pacjentów z województwa mazowieckiego (grupa II), oraz ze względu na charakter analizowanych danych (dane jakościowe, nieparametryczne) do analizy statystycznej uzyskanych wyników wykorzystano nieparametryczny test statystyczny chi-kwadrat Pearsona. Za istotny statystycznie przyjęto poziom istotności statystycznej $\alpha<0,05$.

Zgodnie ze stanowiskiem Komisji Bioetycznej Warszawskiego Uniwersytetu Medycznego badania ankie- towe, retrospektywne i inne nieinwazyjne badania naukowe nie wymagają zgody powyższej Komisji [17].

\section{Wyniki}

Formalności związane z przyjęciem do szpitala są w 42,33\% oceniane dobrze, znacznie wyżej w województwie podlaskim niż województwie mazowieckim $(p<0,03)$. Równie wysoko oceniana jest dostępność do opieki pielęgniarskiej (47,67\%), nieznacznie lepiej w województwie mazowieckim ( $p=0,46)$.

Tabela 2. Ocena jakości opieki w całej badanej grupie pacjentów reprezentujących województwa podlaskie oraz mazowieckie Table 2. Assessment of care quality among the entire group of patients from administrative units of Podlachia and Mazovia

\begin{tabular}{|c|c|c|c|c|c|}
\hline $\begin{array}{l}\text { Lp.//tem } \\
\text { no. }\end{array}$ & $\begin{array}{l}\text { Oceniany obszar/ } \\
\text { Area under study }\end{array}$ & $\begin{array}{l}\text { Ocena bardzo dobra (3)/ } \\
\text { Very good (3) }\end{array}$ & $\begin{array}{l}\text { Ocena dobra (2)/ } \\
\text { Good (2) }\end{array}$ & $\begin{array}{l}\text { Ocena zła (1)/ } \\
\operatorname{Bad}(1)\end{array}$ & $\begin{array}{l}\text { Nie mam zdania }(0) / \\
\text { No opinion }(0)\end{array}$ \\
\hline \multicolumn{6}{|c|}{ Przyjęcie do szpitala - pobyt w izbie przyjęć/Admission to hospital: stay at emergency room } \\
\hline 1. & $\begin{array}{l}\text { sprawność dokonywania formalności związanych z przyjęciem do } \\
\text { szpitala/Fulfilling formalities related to the admission to hospital }\end{array}$ & $74 / 24,67 \%$ & $127 / 27,67 \%$ & $83 / 27,67 \%$ & $16 / 5,33 \%$ \\
\hline 2. & $\begin{array}{c}\text { życzliwość i uprzejmość personelu izby przyjęć/kindness and } \\
\text { courtesy of emergency staff }\end{array}$ & $90 / 30,00 \%$ & $147 / 49,00 \%$ & $43 / 14,33 \%$ & $20 / 6,67 \% /$ \\
\hline \multicolumn{6}{|c|}{ Pobyt w oddziale szpitalnym/opieka pielęgniarska/Stay at a hospital ward/nursing care } \\
\hline 3. & $\begin{array}{l}\text { dostępność opieki pielęgniarskiej w godzinach nocnych/availa- } \\
\text { bility of nursing care at night }\end{array}$ & $114 / 38,00 \%$ & $143 / 47,67 \%$ & $24 / 8,00 \%$ & $19 / 6,33 \%$ \\
\hline 4. & $\begin{array}{l}\text { szybkość reagowania na wezwanie pacjenta/response time to } \\
\text { a patient's call }\end{array}$ & $113 / 37,67 \%$ & $139 / 46,33 \%$ & $31 / 10,33 \%$ & $17 / 5,67 \%$ \\
\hline 5. & $\begin{array}{c}\text { staranność wykonywanych zabiegów, opatrunków, pobierania } \\
\text { krwi, podłączania kroplówek etc./care in performing proce- } \\
\text { dures, applying wound dressings, collecting blood samples, } \\
\text { administering a drip, etc. }\end{array}$ & $178 / 59,33 \%$ & $107 / 35,67 \%$ & $8 / 2,67 \%$ & $7 / 2,33 \%$ \\
\hline 6. & $\begin{array}{l}\text { wsparcie, zainteresowanie potrzebami chorych/support and } \\
\text { sensitivity to the patients' needs }\end{array}$ & $109 / 36,33 \%$ & $124 / 41,33 \%$ & $54 / 18,00 \%$ & $13 / 4,33 \%$ \\
\hline 7. & reakcje na prośby pacjentów/response to the requests of patients & $109 / 36,33 \%$ & $138 / 46,00 \%$ & $40 / 13,33 \%$ & $13 / 4,33 \%$ \\
\hline 8. & $\begin{array}{l}\text { życzliwość i uprzejmość personelu pielęgniarskiego/kindness } \\
\text { and courtesy of nurses }\end{array}$ & $144 / 48,00 \%$ & $124 / 41,33 \%$ & $25 / 8,33 \%$ & $7 / 2,33 \%$ \\
\hline \multicolumn{6}{|c|}{ Pobyt w oddziale szpitalnym/opieka lekarska/Stay at a hospital ward/medical care } \\
\hline 9. & $\begin{array}{c}\text { ilość czasu poświęconego pacjentowi przez lekarza/time } \\
\text { devoted to a patient by a doctor }\end{array}$ & $58 / 19,33 \%$ & $132 / 44,00 \%$ & $101 / 33,67 \%$ & $9 / 3,00 \%$ \\
\hline 10. & $\begin{array}{l}\text { fachowość świadczonych przez lekarzy usług/professionalism } \\
\text { of the services provided }\end{array}$ & $116 / 38,67 \%$ & $140 / 46,67 \%$ & $25 / 8,33 \%$ & $19 / 6,33 \%$ \\
\hline 11. & $\begin{array}{l}\text { wsparcie, wyjaśnienia i informacje udzielane przez lekarzy/sup- } \\
\text { port, explanations and information provided by doctors }\end{array}$ & $72 / 24,00 \%$ & $144 / 48,00 \%$ & $75 / 25,00 \%$ & $9 / 3,00 \%$ \\
\hline 12. & $\begin{array}{c}\text { reakcje na prośby pacjentów/response to the requests of } \\
\text { patients }\end{array}$ & $60 / 20,00 \%$ & $172 / 57,33 \%$ & $49 / 16,33 \%$ & $19 / 6,33 \%$ \\
\hline 13. & $\begin{array}{l}\text { życzliwość i uprzejmość lekarzy/kindness and courtesy of } \\
\text { doctors }\end{array}$ & $91 / 30,33 \%$ & $157 / 52,33 \%$ & $43 / 14,33 \%$ & $9 / 3,00 \%$ \\
\hline \multicolumn{6}{|c|}{ Ogólna ocena szpitala/General assessment of the hospital } \\
\hline 14. & $\begin{array}{l}\text { praca personelu pomocniczego (rehabilitanci, salowe, sanitar- } \\
\text { iusze etc.)/work performed by auxiliary personnel (physiothera- } \\
\text { pists, domestic assistants, hospital orderlies, etc.) }\end{array}$ & $127 / 42,33 \%$ & $149 / 49,67 \%$ & $12 / 4,00 \%$ & $12 / 4,00 \%$ \\
\hline 15. & $\begin{array}{c}\text { stan wyposażenia sal, gabinetów, (pościel, oświetlenie, krzesła, } \\
\text { dostęp do toalety)/the status of the equipment in patients' } \\
\text { rooms and medical rooms (bedding, light, chairs, access to } \\
\text { toilet facilities) }\end{array}$ & $108 / 36,00 \%$ & $125 / 41,67 \%$ & $63 / 21,00 \%$ & $4 / 1,33 \%$ \\
\hline 16. & $\begin{array}{l}\text { przestrzeganie praw pacjenta (np. do kontaktu z bliskimi, po- } \\
\text { szanowania godności etc.)/respecting the patient's rights (e.g. } \\
\text { to communicate with relatives, respect human dignity, etc.) }\end{array}$ & $169 / 56,33 \%$ & $95 / 31,67 \%$ & $17 / 5,67 \%$ & $19 / 6,33 \%$ \\
\hline
\end{tabular}

Źródło: opracowanie własne

Source: author's own analysis 
Opinie pacjentów z obu województw na temat jakości opieki nie różniły się: tylko w jednym przypadku - oceny sprawności dokonywania formalności związa- nych z przyjęciem do szpitala - opinie pacjentów reprezentujących województwo podlaskie i województwo mazowieckie różniły się istotnie statystycznie (Tabela 3).

Tabela 3. Ocena jakości opieki w zależności od analizowanego województwa: podlaskiego oraz mazowieckiego

Table 3. Assessment of quality of care by an administrative unit of Podlachia or Mazovia

\begin{tabular}{|c|c|c|c|c|c|c|c|c|}
\hline \multirow[t]{2}{*}{$\begin{array}{l}\text { Lp./ } \\
\text { Item } \\
\text { no. }\end{array}$} & \multirow[t]{2}{*}{ Oceniany obszar/Area under study } & \multicolumn{2}{|c|}{$\begin{array}{l}\text { Ocena bardzo dobra (3)/ } \\
\text { Very good (3) }\end{array}$} & \multicolumn{2}{|c|}{$\begin{array}{l}\text { Ocena dobra (2)/ } \\
\text { Good (2) }\end{array}$} & \multicolumn{2}{|c|}{$\begin{array}{l}\text { Ocena zła (1)/ } \\
\qquad \text { Bad (1) }\end{array}$} & \multirow[t]{2}{*}{$\begin{array}{l}\text { Nie mam zdania }(0) / \\
\text { No opinion }(0)\end{array}$} \\
\hline & & Maz & Podl & Maz & Podl & Maz & Podl & \\
\hline \multicolumn{9}{|c|}{ Przyjęcie do szpitala - pobyt w izbie przyjęć/Admission to hospital: stay at the emergency room } \\
\hline 1. & $\begin{array}{l}\text { sprawność dokonywania formalności związa- } \\
\text { nych z przyjęciem do szpitala/fulfilling formalities } \\
\text { related to the admission to hospital }\end{array}$ & $12,33 \%$ & $12,33 \%$ & $17,67 \%$ & $24,67 \%$ & $16,33 \%$ & $11,33 \%$ & $\mathrm{p}=, 03786$ \\
\hline 2. & $\begin{array}{l}\text { życzliwość i uprzejmość personelu izby przyjęć/ } \\
\text { kindness and courtesy of emergency staff }\end{array}$ & $17,67 \%$ & $12,33 \%$ & $23,00 \%$ & $26,00 \%$ & $6,00 \%$ & $8,33 \%$ & $p=, 20920$ \\
\hline \multicolumn{9}{|c|}{ Pobyt w oddziale szpitalnym/opieka pielęgniarska/Stay at a hospital ward/nursing care } \\
\hline 3. & $\begin{array}{l}\text { dostępność opieki pielęgniarskiej w godzinach } \\
\text { nocnych/availability of nursing care at night }\end{array}$ & $20,33 \%$ & $17,67 \%$ & $24,00 \%$ & $23,67 \%$ & $3,00 \%$ & $5,00 \%$ & $p=, 46774$ \\
\hline 4. & $\begin{array}{l}\text { szybkość reagowania na wezwanie pacjenta/ } \\
\text { response time to a patient's call }\end{array}$ & $19,67 \%$ & $18,00 \%$ & $23,00 \%$ & $23,33 \%$ & $4,67 \%$ & $5,67 \%$ & $p=, 90155$ \\
\hline 5. & $\begin{array}{l}\text { staranność wykonywanych zabiegów, opatrun- } \\
\text { ków, pobierania krwi, podłączania kroplówek } \\
\text { etc./care in performing procedures, applying } \\
\text { wound dressings, collecting blood samples, } \\
\text { administering a drip, etc. }\end{array}$ & $30,00 \%$ & $29,33 \%$ & $17,00 \%$ & $18,67 \%$ & $1,33 \%$ & $1,33 \%$ & $p=, 67265$ \\
\hline 6. & $\begin{array}{l}\text { wsparcie, zainteresowanie potrzebami chorych/ } \\
\text { support and sensitivity to the patients' needs }\end{array}$ & $21,00 \%$ & $15,33 \%$ & $20,33 \%$ & $21,00 \%$ & $7,33 \%$ & $10,67 \%$ & $p=, 09132$ \\
\hline 7. & $\begin{array}{c}\text { reakcje na prośby pacjentów/response to the } \\
\text { requests of patients }\end{array}$ & $20,67 \%$ & $15,67 \%$ & $20,33 \%$ & $25,67 \%$ & $7,00 \%$ & $6,33 \%$ & $p=, 25127$ \\
\hline 8. & $\begin{array}{l}\text { życzliwość i uprzejmość personelu pielęgniar- } \\
\text { skiego/kindness and courtesy of nurses }\end{array}$ & $26,67 \%$ & $21,33 \%$ & $17,33 \%$ & $24,00 \%$ & $5,00 \%$ & $3,33 \%$ & $p=, 10471$ \\
\hline \multicolumn{9}{|c|}{ Pobyt w oddziale szpitalnym/opieka lekarska/Stay at a hospital ward/medical care } \\
\hline 9. & $\begin{array}{l}\text { ilość czasu poświęconego pacjentowi przez } \\
\text { lekarza/time devoted to a patient by a doctor }\end{array}$ & $10,67 \%$ & $8,67 \%$ & $21,00 \%$ & $23,00 \%$ & $16,67 \%$ & $17,00 \%$ & $p=, 79776$ \\
\hline 10. & $\begin{array}{l}\text { fachowość świadczonych przez lekarzy usług/ } \\
\text { professionalism of the services provided }\end{array}$ & $19,33 \%$ & $19,33 \%$ & $22,67 \%$ & $24,00 \%$ & $5,33 \%$ & $3,00 \%$ & $p=, 46669$ \\
\hline 11. & $\begin{array}{l}\text { wsparcie, wyjaśnienia i informacje udzielane } \\
\text { przez lekarzy/support, explanations and informa- } \\
\text { tion provided by doctors }\end{array}$ & $13,00 \%$ & $11,00 \%$ & $23,67 \%$ & $24,33 \%$ & $12,33 \%$ & $12,67 \%$ & $\mathrm{p}=, 67282$ \\
\hline 12. & $\begin{array}{c}\text { reakcje na prośby pacjentów/response to the } \\
\text { requests of patients }\end{array}$ & $10,67 \%$ & $9,33 \%$ & $29,67 \%$ & $27,67 \%$ & $7,00 \%$ & $9,33 \%$ & $\mathrm{p}=, 58292$ \\
\hline 13. & $\begin{array}{c}\text { życzliwość i uprzejmość lekarzy/kindness and } \\
\text { courtesy of doctors }\end{array}$ & $16,67 \%$ & $13,67 \%$ & $25,33 \%$ & $27,00 \%$ & $6,67 \%$ & $7,67 \%$ & $p=, 71264$ \\
\hline \multicolumn{9}{|c|}{ Ogólna ocena szpitala/General assessment of the hospital } \\
\hline 14. & $\begin{array}{l}\text { praca personelu pomocniczego (rehabilitanci, } \\
\text { salowe, sanitariusze etc.)/work performed by } \\
\text { auxiliary personnel (physiotherapists, domestic } \\
\text { assistants, hospital orderlies, etc.) }\end{array}$ & $23,00 \%$ & $19,33 \%$ & $23,33 \%$ & $26,33 \%$ & $2,33 \%$ & $1,67 \%$ & $p=, 36717$ \\
\hline 15. & $\begin{array}{c}\text { stan wyposażenia sal, gabinetów, (pościel, } \\
\text { oświetlenie, krzesła, dostęp do toalety)/the } \\
\text { status of the equipment in patients' rooms and } \\
\text { medical rooms (bedding, light, chairs, access to } \\
\text { toilet facilities) }\end{array}$ & $20,67 \%$ & $15,33 \%$ & $20,33 \%$ & $21,33 \%$ & $8,00 \%$ & $13,00 \%$ & $p=, 07147$ \\
\hline 16. & $\begin{array}{l}\text { przestrzeganie praw pacjenta (np. do kontaktu } \\
\text { z bliskimi, poszanowania godności etc.)/respec- } \\
\text { ting the patient's rights (e.g. to communicate with } \\
\text { relatives, respect human dignity, etc.) }\end{array}$ & $29,00 \%$ & $27,33 \%$ & $14,67 \%$ & $17,00 \%$ & $3,00 \%$ & $2,67 \%$ & $\mathrm{p}=, 85540$ \\
\hline
\end{tabular}

Źródło: opracowanie własne

Source: author's own analysis 


\section{Dyskusja}

Obserwuje się coraz większe zainteresowanie tematem jakości w opiece zdrowotnej. Wiele z publikacji oraz badania własne wskazują na zadowolenie pacjentów z zapewnianych im przez szpitale usług medycznych [10-17].

Marcinowicz i Grębowski, dokonując analizy 39 publikacji poświęconych satysfakcji pacjentów z opieki zdrowotnej, stwierdzili, że odsetek osób zadowolonych z usług zdrowotnych był znacznie większy niż odsetek niezadowolonych pacjentów [10, 11, 13].

Jednak najbardziej odzwierciedlają to ogólnopolskie badania przeprowadzone w grupie 890 pacjentów z 59 różnych oddziałów szpitalnych. Badania te dotyczyły warunków leczenia, warunków opieki zarówno lekarskiej, jak i pielęgniarskiej oraz przestrzegania praw pacjenta i dostępu chorego do informacji o stanie zdrowia. Badania wykazały, że zdecydowana większość respondentów - od $65 \%$ do ponad $80 \%$ - oceniła pozytywnie poszczególne aspekty funkcjonowania opieki zdrowotnej. Zaledwie $4,5 \%$ ankietowanych wybrało odpowiedzi negatywne. Najczęściej krytyczna ocena odnosiła się jedynie do posiłków zapewnianych przez placówki medyczne [2].

Podobne oceny uzyskano w badaniach własnych. Funkcjonowanie izby przyjęć pozytywnie oceniło 79\% badanych (ocena dobra - 49,00\%, bardzo dobra $30,00 \%)$. Natomiast fachowość wykonywanych czynności pielęgnacyjnych pozytywnie oceniło 95\% (ocena bardzo dobra - 59,33\%, dobra - 35,67\%), zaś lekarzy - 85,34\% (ocena dobra - 46,67\%, bardzo dobra $38,67 \%$ ), a prace personelu pomocniczego oceniło jako dobrą 49,67\%, jako bardzo dobrą - 42,33\%.

Negatywne oceny w przeprowadzonych badaniach kształtowały się na znacznie wyższym poziomie w przypadku funkcjonowania izby przyjęć - 14,33\%; fachowości pielęgniarek - 2,67\%; fachowości lekarzy - 8,33\%; personelu pomocniczego - $4 \%$.

W badaniach przeprowadzonych w 2001 r. przez Centrum Badania Opinii Społecznej (CBOS) wykazano, że $43 \%$ badanych jest zadowolonych z warunków leczenia, zaś $10 \%$ ankietowanych nie potrafiło określić własnego zdania [20].

Podobne wyniki do badań wyżej wymienionych udało się również zaobserwować w prezentowanej w niniejszej pracy grupie pacjentów. Na Mazowszu ogólny stan wyposażenia szpitali pozytywnie oceniło aż $41 \%$ ankietowanych, zaś na Podlasiu - 36,66\%. Ocenę negatywną wystawiło $21 \%$ badanych. Znacznie częściej zła ocena pojawiała się w przypadku badanych z województwa podlaskiego (13\%) niż województwa mazowieckiego (8\%).

Wyniki CBOS ukazały, że jeśli chodzi o równe traktowanie pacjenta, pozytywne opinie są także częstsze niż negatywne [20].
W badaniach przeprowadzonych w 2005 r. przez pracowników Mazowieckiego Centrum Zdrowia Publicznego mimo wysokiej oceny usług medycznych niepokój może budzić wysoki procent respondentów, których nie zawsze pytano o zgodę na dane leczenie lub zabiegi, czy też nie zawsze rozumieli przekazywane im informacje o stanie zdrowia. Prawie połowa pacjentów potwierdziła, że w czasie badań lekarskich były obecne osoby trzecie. Połowy tych pacjentów nie pytano o zgodę na uczestniczenie osób trzecich, a co dziesiąty był pytany tylko czasami $[11,12]$. Nie potwierdzają jednak tego faktu badania własne, gdzie zdecydowana większość - 88\% badanych - podkreśla, iż ich prawa są przestrzegane przez personel medyczny (44,33\% województwo podlaskie, 43,67\% województwo mazowieckie).

Większość badań ukazuje, że doświadczenia pacjentów dotyczące usług, jakie zapewniają im szpitale, są zdecydowanie lepsze niż opinie powszechnie panujące, które w dużym stopniu kształtowane są przez środki masowego przekazu [14].

Media poświęcają sporo miejsca głównie negatywnym przypadkom w ochronie zdrowia - bez wątpienia należy je ujawniać, zapobiegać im, ale jednocześnie nie należy ich generalizować [11].

Zagadnienie jakości opieki zdrowotnej jest podejmowana w piśmiennictwie krajowym w wielu aspektach [21-27].

Dąbrowska-Bender i Steć [21] podejmują próbę ukazania aspektu bezpieczeństwa pacjenta w polskim i szwedzkim systemie opieki zdrowotnej, poszanowania jego praw oraz zapewnienia mu usług medycznych na najwyższym poziomie poprzez m.in.: swobodny dostęp do opieki zdrowotnej, godne warunki pobytu podczas leczenia, należytą informację oraz odpowiedzialność ze strony wysoko wykwalifikowanego personelu medycznego. Bezpieczeństwo pacjenta obejmuje działania o szerokim zakresie i jest jednym z priorytetów w odniesieniu do jakości opieki zdrowotnej. Do działań wpływających bezpośrednio na nie należą m.in.: regulacje prawne, sytuacja finansowa, standardy jakości kadry medycznej, infrastruktury, wyposażenia oraz technologii medycznej. Dotyczy to zarówno szpitala, przychodni, domu opieki, hospicjum, jak też innych miejsc, w których jest udzielana pomoc medyczna. Szwedzki system opieki zdrowotnej uznany jest za jeden z najlepiej funkcjonujących wśród krajów wysoko rozwiniętych. Jego działalność i struktura organizacyjna może zatem stanowić wzorzec zmian usprawniających polski system opieki zdrowotnej.

Owoc i wsp. [24] przedstawili analizę wyników badań dotyczących oceny zainteresowania oraz samooceny wiedzy na temat funkcjonowania opieki zdrowotnej w Polsce. Zbadano reprezentatywną grupę (771 osób) Polaków. Badaniami objęto w 2008 r. pięć województw: 
mazowieckie, zachodniopomorskie, śląskie, lubuskie i lubelskie. Kwestiami reformy systemu opieki zdrowotnej nie było zainteresowanych $50 \%$ badanych. Badani twierdzili, że ich wiedza na temat funkcjonowania opieki zdrowotnej jest wystarczająca, ale $43 \%$ twierdziło, że poziom ich wiedzy jest niski. Na poziom zainteresowania systemem funkcjonowania opieki zdrowotnej w Polsce wpływ miało wykształcenie respondentów - im wyższy poziom wykształcenia, tym większe zainteresowanie opisywanym zagadnieniem. Na poziom zainteresowania systemem ochrony zdrowia miał w badanej grupie wpływ również wiek - osoby starsze były bardziej zainteresowane opisywanym zagadnieniem. Najważniejszymi źródłami informacji na temat systemu były w badanej grupie radio, telewizja oraz prasa. Ponad $40 \%$ badanych twierdziło, że usprawnienie systemu opieki zdrowotnej w Polsce jest najważniejszym zadaniem polskiego rządu.

Badania dotyczące jakości systemu opieki zdrowotnej w Polsce obejmują również analizy dotyczące pojedynczych zagadnień: Szymańska i wsp. analizowali opinie pacjentów na temat pierwszej pomocy, podobne zagadnienie analizowali Kos i wsp., prowadząc badania w Szpitalnym Oddziale Ratunkowym w Kraśniku. Roszkowska i wsp. analizowali jakość opieki prenatalnej w szpitalu w Łomży. Bardzo istotnym czynnikiem wpływającym na jakość opieki zdrowotnej jest w Polsce dostępność do świadczeń i czas oczekiwania na świadczenia zdrowotne, co analizowali w swojej pracy również Ziółkowska i Paciorek [27].

\section{Wnioski}

1. Problematyka jakości opieki zdrowotnej w Polsce jest podejmowana w polskiej literaturze naukowej często, w różnych aspektach, zarówno w formie prac przeglądowych, jak i prezentacji wyników badań własnych.

2. Wyniki badań własnych pokazały, że zarówno ogólna ocena usług medycznych świadczonych w analizowanych szpitalach, jak i poziom zadowolenia z kontaktu z personelem medycznym w województwach mazowieckim i podlaskim są wysokie.

3. Społeczna ocena pracy pielęgniarek i pielęgniarzy była w badanej grupie pacjentów wyższa niż ocena innych pracowników służby zdrowia - lekarzy, co może wiązać się z faktem, iż personel pielęgniarski spędza z pacjentem więcej czasu.

\section{Piśmiennictwo}

1. Głowacka MD, Sobkowski M, Staszewski R. Pomiar i analiza poziomu jakości świadczeń zdrowotnych. Now Lek. 2005; 74, 2: 230-231.

2. Hupert Z. Jakość w opiece medycznej: koncepcja pomiaru. Lublin: Instytut Medycyny Wsi; 2003.
3. Kalinowski P, Jędrzejewska B. Dostępność usług medycznych po reformie służby zdrowia w Polsce - opinie pacjentów. Zdr Publ. 2004; 114: 8-11.

4. Kapica D, Orzeł Z, Draus J. Ocena poziomu zadowolenia pacjentów szpitala ze świadczonych usług zdrowotnych. Zdr Publ. 2001; 111: 26-30.

5. Karaszewski R. TQM - teoria i praktyka. Toruń: Wyd. TNOIK; 2001. 19.

6. Kisiel Ż, Samborska-Sablik A, Gaszyński W. Ocena jakości opieki medycznej na przykładzie Szpitalnego Oddziału Ratunkowego Uniwersyteckiego Szpitala Klinicznego nr 1 Uniwersytetu Medycznego w Łodzi. Zdr Publ. 2008; 118(3): 329-333.

7. Koronkiewicz A, Murkowski M, Nowacki W. Problematyka akredytacji szpitali - przegląd międzynarodowy. Zdr Publ. 1999; 109 (supl. 4): 37-40.

8. Latalski M, Tokarski S. Dostępność świadczeń zdrowotnych na terenie województwa lubelskiego: raport z badań. Lublin: Wyd. Akademii Medycznej; 2003.

9. Marcinowicz L, Grębowski R. Satysfakcja pacjentów w świetle polskich badań empirycznych - próba wyjaśnienia zagadki wysokiego poziomu zadowolenia z opieki. Pol Merk Lek. 2005; 17; 663-666.

10. Miller M et al. Ocena poziomu satysfakcji pacjentów leczonych na terenie województwa mazowieckiego. Warszawa: Centrum Medyczne Kształcenia Podyplomowego, PZH; 2007.

11. Miller M, Supranowicz P. Ocena jakości usług medycznych przez pacjentów szpitali. Prz Epidemiol. 2008; 62(3): 643-650.

12. Miller M, Supranowicz P, Gębska-Kurczerowska A et al. Ocena poziomu satysfakcji pacjentów jako element jakości pracy podstawowej opieki zdrowotnej. Pol Merk Lek. 2007; 23: 367-370.

13. Miller M, Supranowicz P, Targowski M. Ocena jakości i dostępności materiałów edukacyjnych o zdrowiu. II. Opinie pacjentów. Rocz PZH. 2004; 55: 125-131.

14. Opolski K, Dykowska G, Możdżonek M. Zarządzanie przez jakość w usługach zdrowotnych. Warszawa: Wyd. CeDeWu; 2009.

15. Piątek A. Doskonalenie jakości opieki pielęgniarskiej. W: Ksykiewicz-Dorota A (red.). Podstawy organizacji pracy pielęgniarskiej. Lublin: Wyd. Czelej; 2004. 161-184.

16. Piątek A. Zarządzanie jakością. W: Ksykiewicz-Dorota A (red.). Zarządzanie w pielęgniarstwie. Lublin: Wyd. Czelej; 2005. 303-328.

17. Opinia Komisji Bioetycznej Warszawskiego Uniwersytetu Medycznego, http://komisja-bioetyczna.wum.edu.pl/ content/szczeg\%C3\%B3\%C5\%82owe-informacje-orazwzorydokument\%C3\%B3w (data dostępu: 25.01.2014).

18. Tatarkiewicz W. Historia filozofii. Tom I. Warszawa: PWN; 2011.

19. Dykowska G. Jakość usług zdrowotnych - podstawowe informacje, republika.pl/amwaw1/jakość.doc (data dostępu: 25.01.2012).

20. Opinie o opiece zdrowotnej pod koniec drugiego roku reform, http://www.cbos.pl/SPISKOM.POL/2001/K_002_01. PDF (data dostępu: 25.01.2012).

21. Dąbrowska-Bender M, Steć M. Patient safety as part of a health care quality system on Polish and Swedish example. Zdr Publ. 2009; 119(3): 325-330.

22. Kos M, Dziewa A, Drop B. Assessment of satisfaction with hospital care in the ED and the Admissions depending on the place of living. Zdr Publ. 2013; 123(3): 205-209.

23. Kos M, Dziewa A, Drop B. Assessment of patient satisfaction carried out in the Hospital Emergency Department in Kraśnik. Zdr Publ. 2013; 123(2): 122-124. 
24. Owoc A, Bojar I, Owoc J, Pawełczak-Barszczowska A Functioning of the healthcare system in Poland - interest and self-assessed level of knowledge of the surveyed. Zdr Publ. 2009; 119(3): 239-242.

25. Szymańska J, Dubielis W, Horoch A. The quality of first aid services on the basis of patients' opinions. Zdr Publ. 2009; 119(3): 255-257.

26. Roszkowska U, Kulesza-Brończyk B, Dobrzycka B, Terlikowski SJ. The quality of perinatal care in the Cardinal Stefan Wyszyński Regional Hospital in Łomża. Zdr Publ. 2009; 119(3): 258-260

27. Ziółkowska K, Paciorek P. The analysis of factors influencing the delay of the treatment by patients with the chest pain. Zdr Publ. 2009; 119(3): 247-250.
Artykuł przyjęty do redakcji: 15.03 .2016

Artykuł przyjęty do publikacji: 07.07.2016

Źródło finansowania: Praca nie jest finansowana z żadnego źródła. Konflikt interesów: Autorzy deklarują brak konfliktu interesów.

Adres do korespondencji:

Joanna Gotlib

ul. Żwirki i Wigury 61

02-091 Warszawa

tel.: 225720 490, fax: 225720491

e-mail: joanna.gotlib@wum.edu.pl

Zakład Dydaktyki i Efektów Kształcenia

Warszawski Uniwersytet Medyczny 